\title{
The Issues, Challenges and Strategies to Strengthen Technical, Vocational Education and Training in Nigeria
}

\author{
Sylvester Chukwutem Onwusa (PhD) \\ Department of Technology and Vocational Education, Faculty of Education, Nnamdi Azikiwe University, Awka, Nigeria
}

\begin{abstract}
Technical, Vocational Education and Training (TVET) could be a veritable instrument for national economic development in Nigeria. The growing awareness of the need to adapt TVET to meet the rapid global economic requirement is absolutely essential. Thus, TVET is a mechanism that could help for improving the quality of workforce by humanizing their mobility, adaptability and productivity. TVET indirectly could contributes to the enhancement of firms' competitiveness in the globalized world. This is so because one of the most important features of TVET is its orientation towards the world of work and the emphasis of its curriculum on the acquisition of employable skills. Unfortunately, it is sadly to note that, after many years of existence of Nigeria as nation is seriously threatened with unemployment, poverty, social and economic instability, insecurity, corruption, insurgents, banditry, underdevelopment and unscrupulous leadership amongst others. Nigeria will continually remain a technologically backward and dependent nation if this negative attitudes and ugly trends are not reversed. In order to bring lasting solution to these dreadful and horrible situation in Nigeria. It is important that government should focus on acquisition of employable skills for the youths so as to divert there attention from these social vices that have bedevil the nation. Thus, it is absolutely essential to examine the issues, challenges and strategies to strengthen TVET in Nigeria. It was concluded amongst others, that Nigeria government should look inward and recognize the fact that TVET as the bedrock for meaningfully technological growth and national development. It was recommended that the government, stakeholders, policy makers and TVET providers in Nigeria should focus on TVET quality assurance best practices that have worked in advanced countries around the world. Also the government should adequately fund, plan, implement, and manage TVET programmes in technical institutions in Nigeria. Finally there should be a synergy between the schools-industry linkages where students are trained, must be a replica of the environment in which he/she must subsequently work.
\end{abstract}

Keywords: Issues, Challenges, Strategies, Strengthen Technical Vocational Education and Training.

\section{INTRODUCTION}

$\mathrm{E}$ ducation is a major instrument for economic and social development of any nation. The investment in education is considered as investment in human capital development and this could increase labour productivity of a country. Technical, Vocational Education and Training (TVET) is one of the known and authentic process by which excellence, conversant, information literate and knowledgeable workers are prepared, trained or retrained worldwide. According to Park (2005), TVET is the systematic and orderly transmission of knowledge, skills and values to develop a workforce that could enhance productivity and sustain competitiveness in the global economy. UNESCO and ILO (2002) described TVET as anall-encompassing term referring to those aspects of the educational process comprising:- general education, the study of technologies and related sciences, the acquisition of practical skills, attitudes, understanding and knowledge relating to occupations in various sectors of economic and social life. Thus, TVET could prepares human resources for the ever changing world of work. This system of education has been adopted and positioned as a panacea to meets current and future labour market demands. Similarly, TVET could be strategically position to tackle poverty alleviation, weak economic growth and low productivity, social inequality, instability and insecurity, the menace of environmental decadence and poor knowledge of green practices (United Nations Educational, Scientific and Cultural Organization, UNESCO (2019).

Identifying the aptitudes of TVET requires an understanding of the changing world of work, which invariably demands innovative teaching techniques and equipment particularly must be changed to adjust with global expectations Kingombe, (2012). As work and occupationally directed system of education, TVET postulates to enhance individuals' capability, employability, adaptability, career mobility and productivity generally. Accordingly, Bakar (2011) stated that through TVET, countries have produced highly skilled workers, high human capital development, thus advancing industrialization and economic growth. The truth behind this assertion is verifiable in many countries where TVET is implemented in variant modes.

Various literature concludes that China became the manufacturing hub of the world through her organized TVET system. China has equally been acknowledged as the second world largest economy (World Bank, 2017). Although the White House Office Trade and Manufacturing Policy (2018) described the developmental path taken by China as economic aggression, there were still commendable acknowledgements of enterprise proliferations in China where over 300 entrepreneurial parks housing about 24,000 enterprises exist. Likewise, Xinyu (2019) reported that the unemployment rate 
in China urban areas was at $3.8 \%$ in 2018, yet 980 Million Yuan were spent on giving vocational training to the jobless. TVET undoubtedly plays commendable roles in the labour market of China.

Similarly, the significant impact to the labour market potentials of TVET is the German-style method of vocational education called Dual TVET where there is two-fold education in which schools and firms share responsibility for providing TVET through apprenticeship training (Remington, 2017). The major strides of German dual system are in the supply of highly skilled labour in accordance with the demand of the highly technologically driven economy, making certain the quickest transition from school to work thereby ensuring that the youth unemployment remains low (Remington, 2017; 2018). According to Trade Economics (2019), the unemployment rate of Germany stood at $3.1 \%$ in August 2019. TVET automatically helps to improve the economic and the labour- market in Germany.

Likewise, in August 2019, Malaysians' unemployment rate was reported to be $3.4 \%$. In the case of Malaysia, the current employment upsurge in Malaysia could be attributed to the initiatives to prioritized entrepreneurship in TVET context, Malaysian TVET style is embedded in three models which are; a liberal model where industries dictate the skills and knowledge; the bureaucratic model where the power rests with the government and the dual system noted for partnership between institutions and industries. It implies that in the fusion of the three models, Malaysia seeks to utilize the full benefits of TVET and achieve the envisaged industrial revolution.

Overall, studies validate and continually applaud the labour market potentials of TVET - as education for work (Park, 2005; Bakar, 2011). However, the issue of the mismatch persists (Remington, 2018; Capelli, 2014; Deloitte and Manufacturing Institute, (2015); McGowan and Andrews, (2015); Organization for Economic Co-operation and Development (OECD), (2016); Wright, (2013); Hoffman and Schwartz, 2017); non-recognition of higher qualification (Ismail. Adnan, Masek, Hassan, Hashim. \& Ismail, 2018). The bigger challenges lie on technical college graduates could not fitting into the supposed careers due to poor practical skills resulting from training conducted using obsolete equipment, thereby requiring retraining by the industries.

In addition, there is a great gap between the two providers of TVET (public and private) in Nigeria. The private sector provides trainings that are directly profitable to its sustainability, often inconsistent with the public sector (Akoojee, 2016). The public sector on the hand faces great challenges of meeting with demands, management and funding of TVET alone without a clear guideline on exploring the private sectors. There is a need for the government to adopt UNESCO's recommendation of transforming its role to a regulator and not the sole provider of TVET for advancement and development (UNESCO, 2012).
Furthermore, TVET could also fosters gender equality campaigns across policy documents. The issues of traditional and non-traditional occupations with respect to the female counterpart was bridged by granting equal access to career paths making TVET an inclusive education (Dee, 2007). However, what is the current situation of TVET concerning a quick transition to labour market? Again, how relevant is the extent to which the labour market demands were met and effectiveness evaluates achievement of objectives while efficiency explores the correlation between inputs and outputs.

\section{HISTORICAL BACKGROUND OF TVET IN NIGERIA}

Long before the Europeans arrived, education has been acquired through practiced in Nigeria. The indigenous African tradition and culture is solely based on skill acquisition and development, from farming to hunting, traditional medicine to craft, apprenticeship was based on watch, observation and do as I do is the system of learning techniques and skills needed to be a master craftsmen in one's field of vocation. The youths were taught their culture, social activities and survival skills for work. Although occupations varied according to the geographical area in Nigeria, Mkpa, (2014) noted that traditional education in most parts of Nigeria trained individuals to fit usually into their society by learning and practicing economic skills for self-sustenance; adapting to their role expectations and contributing to the development of their society. The traditional education offered by the community was comprehensive such that it provided training in physical, character, intellectual, social and vocational development. As observed by Mkpa, there were little or no cases of unemployment. Owolabi, (2003) concluded that the role of traditional education among various ethnic groups in Nigeria was training along technical and vocational lines. Technical and vocational forms of training are available in such fields a farming, fishing, weaving, and carving. Handicraft, knitting, leather work, iron and gold smiting and trading etc. Apprenticeship method was used for thetraining of youths into practicing different family occupations. Accordingly, Owolabi, traditional professions of priesthood, medicine, law, military, administration and other specialist area with recognized training procedures were the cardinal aspects of traditional education.

The arrival of the missionaries introduced western education into Nigeria in the early 1840s. The British colonial government did not promote education. The schools were set up and operated by Christian Missionaries. The policy of the government was to give grant to mission schools rather than expand the system. The western education brought a new emphasis on the objective of educating the young ones. Furthermore, Owolabi, (2003) noted that the sort of training given by the missionary schools produced clerks for government departments and trading companies, interprets for the missionaries, pupil teachers for emerging school system and letter writers for the communities. Attention of the illiterate local people was drawn to the novel development in 
youth training though the missionary schools. Interest in schooling gradually grew as it offered new forms of occupational opportunities to youths. Ability to read and write mattered to the missionaries, the colonial government and the local people. Psychologically the indigenous people were made to see their traditional education as inferior. Traditional education lost its value to western education. This had negative influence on education (TVET in particular) in Nigeria today.

At the turn of $20^{\text {th }}$ century, government departments had staffing problems in the areas of government found the necessity for TVET; and realized that they need technically trained Nigerians to run/manipulate machineries for the imperial economically endeavor. The colonial government was forced to re-look outward. As a result, some government departments/agencies (e.g. Nigerian Railways Corporation, Government Survey School, Marine Department, Posts and Telegraphs Department, Department of Agriculture) initiated technical and vocational trainings. Also, its educational policy of assistance to its colonies was strengthened by sending some Nigerian students to England for training. This informed the subsequent British Foreign policy and educational reforms from 1861-1950.

The Phelps-Stokes report of 1922 recommended that education be adapted to community needs i.e. agricultural education for urban areas. Following proposal of E.J Hussey, the first director of education in Nigeria, Yaba Higher College was established in 1932 to train vocational assistants in medicine, engineering and agriculture. The Elliot commission set up in 1943 recommended in 1945 that the Yaba Higher College be turned to technical institute and of similar technical institutions be established in Kaduna and Enugu. Although the Ashby Commission set up in 1959 noted that education in Nigeria laid much emphasis on literary education, however its recommendations did not favour TVET as it brought about the closure of the three Colleges of Arts, Science and Technology at Zaria, Ibadan and Enugu. These colleges were taken over by Ahmadu Bello University Zaira, Obafemi Awolowo University Ife (formerly University of Ife) and University of Nigeria Nsukka respectively.

However, vocational education was introduced during the colonial era,to train students to fit and fill responsible posts in different government departments to develop the economy (Obioma, 2010). Moreover, those admitted to the vocational and technical training were from poor background and the less academically endowed. Thus. TVET was perceived as education for less privileged and those that cannot do well in academics. Furthermore, the heavy financial and material investment required for TVET made it difficult for missionaries to venture into this area, which negatively affected the development of TVET.

\section{Statement of the Problem}

Nigerian inherited colonial education system did not focus on, manpower development for sustainable economic development. As a result, Nigeria re-charted its educational pathway. TVET was elected as a core aspect of education and launch Nigeria into a dynamic and self-reliant economy. Unfortunately, this dream has remained frustratingly elusive as demonstrated by the high rate of unemployment, low technology development, and high rate of school drop-out, weak economy and limited wage opportunities. The problem of juvenile delinquency and crime can be reduced if the youths are given the necessary vocational training that will keep them busy. Thus, TVET delivery in Nigeria has been criticized of poor quality, very high cost, training not suited to actual social-economic conditions, neglect of the informal sector's needs, and indifference of labour market needscharacterized by high unemployment rate among graduates (Atchoarena \& Delluc in Oketch, 2009).

As rightly observed by Afeti, (2006); Obioma (2010) stated that the critical factor in the actualization of Nigerian economic reform policies is the mass production of people with requisite skills and competencies in TVET. One sure measure for including traits that drive higher value is exposing the populace to comprehensive functional education and training as provided by TVET. Regrettably, TVET in particular has not received adequate financial attention in Nigeria (Eze \& Okorafor, 2012). The negligence of TVET is socially and economically injurious, as it robs the nation the contribution of graduates in national development.

Therefore, it is miserably to note that, after many years of existence. Nigeria is still faced with unemployment, poverty, social and economic instability, insecurity, underdevelopment, corrupt leadership amongst others. In spite of the abundance of natural resources inherent in it. This is very closely connected to poor development of human potentials in the country to effectively harness the resources. Nigeria educational system has fallen short of expectation in meeting the needs of the society at large. The introduction of TVET in the Nigerian education system, have remained unrealistic, due to a couple of challenges. TVET could be strengthened to achieve its goals and hence drive the transformation of Nigeria economy.

\section{Technical, Vocational Education and Training (TVET)}

As earlier said, TVET is an essential driving force for the socioeconomic growth and technological development of any nations as its focus is oriented towards the workplace and its curriculum emphasizes on the acquisition of employable skills. Technical and Vocational Education and Training (TVET) is that aspect of education that exposes the learner to acquisition of demonstrable skills that could be transformed into economic benefits (Akerele, 2007). TVET seen worldwide is globally recognized for its part in preparing individuals with practical skills to excel in a dynamic work environment (Oviawe, 2018). Similarly, TVET prepares individuals to work in areas which require very specific skills in trades which are often practical in nature, such as electrical installation and maintenance works, motor vehicle mechanics works, fabrication/welding craft practice, bricklaying / block 
laying and concreting etc. Furthermore, The International Labour Organization (ILO) recommendation of 2000 and the United Nations Educational Scientific and Cultural Organization (UNESCO) on TVET for the 21st century described TVET as a:

- Means to facilitate the alleviation of poverty;

- Mechanism to promote the environment for sustaining development;

- Part of long time learning and preparing;

- Way to prepare for world of work and occupational fields and

- An integral part of general education (Umunadi \& Uwameiye, 2015).

The descriptions above indicate that the overall goal of TVET is to instil the right attitude, develop skills and knowledge which is required to enter and progress in the wolrd of work..Finally, TVET is an instrument for skills and knowledge to assist its recipients to become useful to the society in which they live. From the above outlined goals, it is very clear that the essence of TVET is to serve mainly a vehicle for achieving economic development and prosperity in a Nation through economic emancipation of individual citizenry.

\section{Objectives of TVET}

Accordingly, Federal Republic of Nigeria, -FRN,(2013) stated the following objectives of TVET are to:

- Provide trained manpower in applied science, technology and business particularly at craft, advance craft and technical levels;

- Provide the technical knowledge and vocational skills necessary for agricultural, industrial, commercial and economic development;

- Give training and impart the necessary skills leading to individuals be shall be self-reliant economically;

- Provide people who can apply scientific knowledge to the improvement and solution of environmental problems for the use and convenience of man; and

- Give introduction to professional studies in engineering and other technologies

\section{The issues of TVET in Nigeria}

Technical, Vocational Education and Training is designed to offer persons the opportunity of improving themselves in their general proficiency, especially in relation to their present or future occupation. Nuru (2007) opined that changes in any nations' economy is required to prepare youths for future jobs in technical and vocational education have crucial roles to play. May, Ajayi, Arogundadade, \& Ekundayo, (2007). observed that technical and vocational education are still neglected in the aspect of adequate funding, personnel, modern facilities, staff motivation which consequently are robbing the country of the economic development to be contributed by graduates of technical/vocational education. Okoye, and Arimonu,.(2016)maintained that there is an urgent need for the Nigeria's to be redirected towards self-reliant and sustainable means of livelihood which technical education provides. Most analysts agreed that employers of labour today demand more skills than they did in the past (Yang, 2008). Oranu (2010) also observed that there are many factors that have contributed to the ever rising demand for skills in the labour market which include the following; technological and organizational change, trade, deregulation of key industries and the decline of unions.

One of the major issues arising in Nigeria education system is the too much emphasis on University education has always reduced the economic opportunities of those who are more work oriented than academics (Ojimba, 2012). Not everybody needs a University education. Who would employ them if everybody becomes a University graduate? Many of the so called expatriate engineers receiving huge sum of money in dollars for road construction in Nigeria. But in Nigeria, the issue of TVET is not taking seriously. The nation's poverty level has increased to about $75 \%$ that many Nigerians now live on less than one dollar a day. As earlier stated, higher institutions in Nigeria lack the tools and machines to train students to acquire the skills needed by employers of labour. TVET can contribute greatly to the reduction of abject poverty, hunger and unemployment because it is handicapped by numerous challenges (Eze, 2013).

Therefore, it is very important for Nigeria government as a matter of urgency to organize regular vocational training for the youths in different trades and provide starter pack and empower them for self-employment. Also parents/guardians should be encourage to enroll their children in technical institutions to acquire requisite skills for living. The researcher is of the opinion that skills acquisition should also be integrated into University education programmes during students' course of study. Students could graduate from University education with certificate as well as saleable skill. Thus, University graduates could become entrepreneur, job creator and not job seeker and become self-reliance in absence of government employment. This is because the government may not be able to provide employment for every graduate at the same time. If this is done, theyouths may likely contribute meaningfully to the economic development of the nation.

\section{The Challenges of TVET in Nigeria}

Over the years, Nigerian TVET programmes are bedeviled with numerous challenges that have been affecting TVET programmes both in output and input (Afred \& Kayoma, 2012; Oganwu, 2011; Okoye \& Okwelle, 2013; Onyesom \& Ashibogwu (2013); Uwaifo \& Uwaifo, 2012).According to these authors' opinion and views, the challenges include inadequate funding of TVET; inadequate infrastructures; poor power supply; shortage of qualified TVET teachers/instructors; poor supervision of TVET programmes; inadequate curriculum planning and implementation. Accordingly, Nwogu and Nwanoruo (2011), Olaitan (1994) in 
Odu (2011), stated that the challenges of TVET are numerous, which include inadequate human and material resources in terms of quality and quantity; poor funding of TVET, inadequacies in infrastructural facilities; poor quality preparation of lesson by TVET teachers; and social vices. According to Mohammed (2005) in Ayonmike (2013), one of the problems of Technical and Vocational Education in Nigeria is the lack of motivated teachers and the reason for this lack of motivation could easily be traced to the low esteem of the teachers. Additionally, Okafoafor, (2010) posited that the lack of funds on the other hand affects other essentials needed in the implementation of technical education like the provision of teaching aids, furnishing of offices, laboratories, workshops and even basic infrastructures like classroom, seats and tables, so that a common sight to find students of architecture for instance sharing a table where each ideally should have one because of the technical nature of their course.

Ekpenyong (2011) in Ayonmike (2013) posited that, there are a number of factors, which have in various proportions hampered the smooth implementation of the objectives of TVET. According to the National Board for Technical Education (NBTE, 2011), the underlining challenges of TVET sector include; low societal recognition, which translate to low enrolment and inadequate skilled workforce, obsolete instructional facility, inadequate funding, poor staffing, poor linkages with industry and general deficiency in quality. In addition, evaluation in all sectors of education tends to be by conventional examinations, which generally does not factor in practical techniques in the industry. Oranu (2004) observed that the good intentions of successive Nigerian governments about TVET programmes are still fraught with a lot of challenges. The major challenges listed by researcher are explain below.

\section{Curriculum of Technical Vcational Education:}

The curriculum of a subject with practical content is generally organized into an average of $65-70 \%$ for the theoretical classes and 30-35\% for workshop. Olunloyo (2002) noted that one of the issues confronting the design of appropriate curriculum for technical education is preparing students for the shift from the conventional to Information Communication and Technology (ICT) paradigm in technology practice. The low pace of industrialization and technological growth in Nigeria can be attributed to the widening gap between science and technology as a result of the inability of technical education to adequately utilize the scientific ideas to promote technology. This suggests the need to overhaul technical education curricula in Nigeria. The overhauling of the curricula may not necessarily translate to the production of highly literate technical education experts of ready-made graduates for the industry which may result in rapid industrialization or economic growth of the nation unless solutions are proffered to some constraints that may militate against positive outcomes, but will adequately equip our youths with the relevant skills needed for their daily living.
Ojimba, (2012) identified six problems associated with the current curricula in TVET in Nigeria:

- The curricula are simply based on foreign model which has evolved under ideal conditions staff, equipment, infrastructure, training opportunities, which are not easily duplicated in developing countries.

- There is a basic lack of textbooks in the area and most of the available textbooks have foreign background and often illustrated with examples from outside the local environment.

- There is usually a shortage of highly competent indigenous teaching and support staff with sufficient practical experience of technology.

- The curricula are adjudged to be too academic and overloaded with intellectual content in pure science and mathematics at the expense of basic engineering and technology.

- Inadequate provision of humanities, social sciences, business management concepts and entrepreneurial skills development. Because of the inadequate preparations of the students for the industry, some employers retain the graduates to make them productive in their organizations.

- The teaching approach follows the conventional method of transferring knowledge across through the lecturer reading out to the students, who would then take down notes. The educational system continues to place considerable value on this method of teaching.

\section{Access and Equity:}

The road map of Nigeria education sector reported that 16 percent of the turn-out of Junior Secondary is enrolled in Senior Secondary, and the remaining 84 percent constitute potential TVET population (FME, 2009). Unfortunately, the number of TVET institutions in the country cannot take up to 10 percent of this population. Those with the greatest needs do not participate nor benefit from available TVET programmes. Poor children cannot afford training fees. Again good technical and vocational schools are located in big towns, thereby limiting access to rural folks. Inequalities of provision persist between urban and rural and rich and poor where the richest 20 percent of the student population completes on average 9.7 years of schooling compared to a 3.5 years average for the poorest 20 percent (UNESCO, 2010).

\section{Public perception/Estimation:}

Since the advent of western education, TVET is regarded as career path for less academically endowed, rather than effective training to produce skilled workers for employment and sustained livelihoods. Hitherto, secondary education is bias towards the traditional literacy and academic subjects, resulting in the neglect and lack of respect for TVET. Thus TVET has suffered from low standing. Billet (2009) argued 
that dealing with TVET is as though its contribution are not fully appreciated or understood and its status is shaped by societal views and sentiments about the learning of vocational knowledge and skills. For many parent and student, TVET still remains a second class education mostly in developing nations. In Nigeria parents and students resisted streaming into vocational line after junior secondary, due to erroneous stigmatization of the so called non-academic course (technical and business). The present obsession about University education in Nigeria hampers economic development prospect of teeming mass who are better endowed with vocational skill than intellectualism.

\section{Economic Relevance of Vocational Training:}

Analysis of TVET system points to a mismatch between demand for skills and supply for skills. This is not surprising, as the conventional TVET curriculum development established weak link between industries and training institutions. Eze and Okorafor (2012) noted that TVET curriculum in Africa has remained as colonial legacy. Not satisfying the aspirations for educational reforms, yet conformed to large extent, to the system in the colonial country. They were of the opinion that if TVET"s philosophy must be realized, its curriculum must be indigenous, through out by the people, and agreed to the peoples aspirations and conditions of their natural environment, in accordance with the resources at their disposal and particular genius of their culture.

\section{Apathy of political holders/law makers:}

Education generally including technical and vocational education programme has been grossly neglected in Nigeria. Technical educators have the greatest challenge of convincing the law makers on the reasons they should give priority attention to the programme in resources allocation. Many options of getting positive results have been advocated at different mediums namely; politicization, participation of technical educators in governance and encouraging etc. yet the government is still playing a lopsided attitude to the proper development of the programme in Nigeria. Therefore, Nigeria will ever remain a technologically backward and dependent nation if this negative attitude and trend is not reversed.

\section{Enrolment and Gender Disparity:}

There are low and great imbalance in students enrolment in TVET as very few females enroll into the programme. In Nigeria, only 3.6 percent of senior secondary school students were enrolled in TVET in 2005 (Federal Government of Nigeria, FGN, 2009); the 3.6 percent constituted 92,216 students, out of which 86.1 percent were male and 13.9 percent female (FME, 2009). According to UNESCO-UIS report of 2009, in 2007, 3 percent out of 166000 enrolled in TVET in Nigeria. Similarly FME (2009) reported on the average, a 2.5 percent enrollment in TVET at the secondary level as against the modest NPE target of 20 percent.

\section{Inadequate Provision of Funds:}

Despite the attention given to TVET by many governments, the training system in most developing countries is lack of funds. Oketch (2009) was of the opinion that a look at the funding of TVET can shed light on the contradiction between the emphasis for skills and the limited funding those governments are willing to commit to it. Moreover, the international pressure on countries to meet their Education forAll goals for 2015 has meant that more resources have been shifted, both within national budgets and by international aid assistance, to realize Universal Basic Education (UBE), still the rhetoric over skills and the value of TVET continues unabated. Generally, the provision of TVET and especially funding of TVET is really expensive (Prosser cited by Nnajiofor, 2014). Best estimates have shown that Nigeria spends about 2.3 percent of GDP on education, less than half the percentage of GDP spent by the 19 sub-Saharan. African countries on average (FGN, 2009). According to Okoye and Arimonu, (2016). stated that the available data indicate that 20.9 percent, 7.1 percent and 13 percent of total expenditures on education in 2003, 2004 and 2005 respectively went to the NBTE (the statutory body in charge of TVET in Nigeria); of which 39.2 percent, 83.6 percent and 78.4 percent of yearly budget appropriations to NBTE in the same years were actually spent

\section{Non Utilization of ICT in Technical and Vocational Education.}

One of the current challenges in technical and vocational education is the delivery of teaching and learning activities based on ICT (Information Communication and Telecommunication. Integration of ICT in vocational education would greatly benefits the teachers and students in the following ways:

- Tool to communicate and disseminate information on-line;

- Tool that support and help to improve teaching and learning activities;

- To motivate and interest students and

- Learning system that provide greater flexibility. ICT technologies are becoming increasingly important in the development of technical vocational education in this day and offers great potential in improving the quality of vocational education (Ministry of Human Resources 2008; UNESCO 2008).

\section{Nigerian Value System:}

In Nigeria today too much emphasis is placed on University qualifications not minding whether the holder possesses the required knowledge and skill. But in advanced societies those with technical degrees are highly regarded. In fact, the value system in those countries depend on the person's skills and knowledge, and not on the stack of academic degrees one has. In the public service, graduates of technical education are often discriminated against and their career prospect limited. 
For this reason, secondary school leavers and parents prefer University Education to technical education (Nworlu-Elechi, 2013).

\section{THE NEED TO STRENGTHENTVET IN NIGERIA}

\section{a. Weak Economy:}

Nigeria falls within the developing nations. Although it is an irony and unfortunate that Nigeria, the sixth largest exporter of crude oil is hosting the third largest number of poor people after China and India. 71 percent of Nigerian population lives on less than US \$ per day and 92 percent live on less than US \$2 per day (UNESCO Institute for Statistics, UIS, 2009). However, Nigeria falls 20 countries with the widest gap between the poor and the rich. It has a Gini index (measure of gap between the rich and the poor) of 46.5 in 1996, 48.8 in 2010 and 39.7 in 2011 (World Bank, 2013). Nigeria's human development index (HDI) is ranked 153 out of 185, behind countries like Malaysia (64), Brazil (85), China (101), South African (121), Ghana (135) and India (136) (UNDP, 2013). Nigeria has made a less than impressive show in the latest Global competitiveness Index for 2019/2020, a survey aimed at identifying the quality of the macroeconomic environment, the state of a country's public institutions and its level of technological readiness.

\section{b. High Rate of Unemployment:}

The truth is that the unemployment level in Nigeria remains a dangerous one to the extent that even countries that witnessed the Arab Awakening did not have such high level of unemployment. Could you imagine what happened early 2014 where hundreds of thousands of youths applied for less than 4500 vacancies in immigration service? There were stampeded that led to death of not less than 20 youths in the country (see dailies of March 16, 2014). National Bureau of Statistics (2012) reported that unemployment rate at 56 percent. The nation's youth under/unemployment is shooting up the sky. Graduates find it difficult to fit into any type of skilled or semi-skilled labour, while at the same time it is becoming apparent that the majority of them cannot afford the expenses to further their education. The Nigerian education system equips them with book knowledge for office work that hardly exists. In other words, there is a mismatch between training and labour market skill demands. This ugly situation has kept Nigeria in perpetual bondage of economic frustration and calls for a rethink of the nation's education system, particularly TVET.

\section{c. High Rate of School Drop-Out:}

The average school completion rates in Africa are 80-90 percent for primary schools, 30-40 percent for Junior Secondary, about 20 percent for Senior Secondary and only 12 percent of the college age group actually enters tertiary institutions (African Union, 2007) Sub-Sahara Africa (SSA) accounts for 47 percent of the world's out of school children and 54 percent of this group are females (UNESCO, 2009) In a similar vein, UNESCO (2010) observed that 32 million children are out of school in sub-Sahara Africa. The female adult literacy rate (age 15 and above) for Nigeria is 59.4 percent, and the male adult literacy rate is 74.4 percent (Wikipedia, 2013). It could be asserted that many young people drop out of school before they acquire any practical skill and competency for the world of work. These groups can be taken care of by different forms of TVET.

\section{d. Increase in Crime Rate:}

The Nigerian security issues pertain more to the people and national development, rather than the military and territorial defense. So many uprisings, insurgences that result in destruction of lives and property in various parts of the country have their roots in illiteracy and idleness. Many unemployed youths embrace crime, law-breaking and criminality as represented by armed robbery, cultism, prostitution, fraud stars (yahoo boys), and stealing by false pretenses among other vices; yet a sizeable percentage are also indoctrinated to embrace extremism and terrorism (Kayode, 2013), National Bureau of Statistics, NBS, (2012) recorded that since 2009, more than 104 foreign nationals have been kidnapped in Nigeria. Off course we dare not talk about Nigeria citizens that have been kidnapped since it has turned to a daily occurrence. Imagine in a State where bandits and insurgents invade a police station, disarm the police in a broad day light and hold the police in hostage for about an hour while attacking a bank just about 100 meters from the police station. This incident took place on $15^{\text {th }}$ October 2013 at Markarfi divisional police station in Kaduna State (naijapals.com, 2013).The same naijapals.com (2013) reported that a businessman was killed in Lagos for refusing to settle area boys.

\section{STRATEGIES TO STRENGTHEN TVET IN NIGERIA}

\section{a. Development of indigenous curriculum}

The main idea behind any functional TVET program is to fill the need of the immediate environment then beyond the environment. It is time to use own initiatives in developing the curriculum that is relevant to economic and social needs of the society. TVET curriculum should be revised to shift from single to multiple skills, build from local market opportunities to foster local innovations and technologies than over dependence on imported ones. Inasmuch as Nigeria desire to join in the global technological train, it must put into consideration the conditions of its natural environment, culture and resources. Eze and Okorafor (2012) opined that relevant curriculum will attract the right people and engender the use of local ideas, tools and materials. Thereby minimizing dependence on imported technologies and products and stimulating the intellect of Africans to improve indigenous technologies and materials.

\section{b. School-industry linkages:}

In this era of globalization were knowledge and problem solving trump manual skills, TVET training institutions no longer function as isolators' component in the labour market. 
It will be a good strategy to work out a close co-operation between TVET schools and employers to adapt existing materials to the training needs of changing occupations. This will make it possible to improve the match between training provision and demand, and to mobilize additional resources for effective training in the schools. School-industry linkage can be achieved through; constitution of advisory and curriculum development committees with members representing employers and the schools, vocational guidance and placement activities, surveys of local employers, and training strategies that include periodic, supervised placement of trainees for work experience (Okorafor, Uduanochie \& Achukwu, 2014; Nnajifor, 2014). Further to this, utilizing information on employment rate by skills levels, economic returns on different levels of training current vacancy rates, and employer projections employment opportunities are likely to expand in the medium term. Such feedback enables training agencies and institutions to meet the training needs of the clientele and the world of work (Ibeneme, 2013).

\section{c. Attitudinal re-orientation}

Accordingly, Valmonte (2009) asserted that developing awareness is the first step of re-orientation- a process which encompasses imbibing better principles, skills, perspectives and values. It is only when the leaders and the public are aware of the contributions of TVET that there can be a strategic educational program for producing a productive workforce that can move the nation forward; rather than educational program for academically less privileged. This can be done through campaigns, workshops, exhibitions.

\section{d. TVET teachers professional development}

Qualified teachers in field of TVET are in short supply. There is the urgent need to revitalize the Technical Teachers Training program, TTTP's initiative of the Federal Government. This will enhance tuning out in good quantity and quality, the number of TVET teachers that will facilitate the achievement of TVET goals. Beside, TVET teachers should be supported for advanced capacity development through scholarships and fellowship award. Technical teachers should be given additional incentives to develop their ICT capacity; this will go a long way in expanding training opportunity for TVET.

\section{e. Inclusion of entrepreneurial skills in TVET in Nigeria}

It is unfortunate that even the graduates of TVET are among the sea of unemployed youths in Nigeria it is no doubt that the technical skill is very important, but also very important is the knowledge on how to put those skills to use. Having the technical skills with poor entrepreneurial knowledge on how the use the skills, is like having fine shoes but badly wounded feet to put them on. TVET students/trainees should be exposed to the business environment. In the view of Ibeneme (2013), the entrepreneurship program should cover contents as achievement motivation, market environment, financing, product selection, marking, skill development, management, production, procurement, personnel, legal systems and communication skills. It can be adapted in low skill occupations in which entry is easy because of low capital requirements.

\section{f. Expand training opportunities and facilities}

There is need to expand TVET institutions and facilities. However, care must be taken not to compromise quality; as one of its philosophy states that TVET should not be attempted if it cannot be adequately provided for (Prosser in Nnajiofor, 2014). The new information technology (IT) has the potential to enhance the flexibility of TVET delivery to accommodate poor candidates that cannot afford to be out of workforce for the training, even when it is free. Systematically, IT could be employed in offering shorter, but more intensive course or providing training at convenient time and locations. However, this demands that teachers" ICT capacity be developed.

\section{g. Provision of resource centers}

Vocational educators believe that meeting the recurrent costs of paying qualified managers and instructors and providing up-to-date teaching materials and maintenance are essential to achieving good training outcomes. Since the provision of facilities for TVET is very costly, it would be wise to provide a well-equipped central resource center that can serve many schools within a geographical region. This will also enhance collaboration and exchange of ideals.

\section{h. Support for small scale enterprises}

The business environment in Nigeria is very hostile. The exorbitant charge extorted from entrepreneurs has pushed some out of business. Indigenous small scale industries should be encouraged through reduced tax and other rates. They should also be given loans with minimal interest rates, although, most affluent Nigerians prefer to invest their money in commerce instead of industries. The claim that inadequate physical infrastructures such as transportation, electricity, telecommunication and water supply hinder industrialization is to ignore the fact that these infrastructures are the products and not the agents of industrialization. Proliferation of small scale industries will reduce the much value attached to certification in Nigeria thus competency in job performance will be appreciated. The much discrimination in the type of institution (University, Polytechnics and College of Education) and type of training (formal or informal) will be minimal. As a result, more candidates will enroll into TVET programmes.

\section{THE IMPORTANCE OF TVET FOR NATIONAL DEVELOPMENT}

1. TVET addresses technological change. The acceleration of changes in technologies prompts the industries to higher highly skilled workers. Without them, it would be difficult to reap most of the returns from technological progress 
2. TVET contributes to capital-skill complementarities. According to Ashton and Sung, (2002) a higher level of human capital enables machinery and plants to be used more efficiently, raising the rate of return on investment. Investment in physical capital equipment, is an important determinant of growth. But, it needs a highly skilled worker to master technologies in newly acquired capital equipment.

3. TVET addresses trade openness, competition and foreign direct investment (FDI). With globalization, skills, rather than the resource base of the region determine their competitiveness. Globalization raises the capital flow, which, in turn, raises the demand for skilled manpower. A lack in highly skilled labor may deter the flow of FDI to that particular country.

4. VET addresses changes in work organization. The demand and effective use of skills within enterprises depend on the ways in which work is organized. The changes of organization and work practices in high performance enterprises have an implication on the skills required of employees. In this type of organization, there are self-managed work teams, multi-skilling, job rotation and cross training and the devolution of decision making (Aston \& Sung, 2002). It only works if employees acquire technical skills in addition to those normally required in a traditional organization (Ashton \& Sung, 2002).

5. TVET improves productivity. With the acquisition of skills, workers are more productive and able to produce more output for a given amount of time and effort. Productivity also depends on the work of team members. Through TVET, they learn to work with one another about doing the job effectively and efficiently. This is true when they undergo on-the-job training.

6. TVET delivery systems are well placed to train skilled and entrepreneurial workforce that some countries need to create wealth and emerge out of poverty. The problems of unemployment and reduces the number of people who depend on government for job. When the youths and adults are trained vocationally or technically, it would enable them to be self-reliant in different areas such as electrical, plumbing, automobile, vulcanizing, computer engineering, GSM repairs, and cloth weaving and so on.

7. TVET is always serving as a motivating force in individuals to work for the national development because it stimulates technological and industrial development through the production of competent and honest workers who are capable of utilizing the abundant natural and human resources available in a country for economy and industrial growth and development.

8. TVET could help to bring about rapid economic development. The survival of individuals will ensure the survival of the country as a nation. To continually meet the needs of the present generation means there must be continued economic growth.

9. TVET also encourage local technology could be developed by indigenous technicians and technologists. It should be emphasized here that every society has its own peculiar problems. Therefore, it will take the ingenuity of local artisans, craftsmen, technicians and technologists to design and fabricate tools, equipment and simple or complex machines to solve local problems

\section{STRATEGIES FOR IMPLEMENTATION OF FUNCTIONAL TVET IN NIGERIA}

Functional TVET should be implemented in three different ways. These are:

\section{School-based TVET}

a. Compressive high/secondary schools Here vocational subjects are offered as elective subjects and students take these subjects according to their interests and aptitudes. In our school system, several vocational subjects are offered mainly for those who have no inclination toward academic field. Some vocational subjects are offered also to students who are good academically. They take the subject as an elective.

b. Vocational and technical schools. Here vocational education takes place mainly in vocational and technical schools at the secondary level. These institutions run parallel with academic schools but are focused on TVE. Presently, technical and vocational schools is three-year programme.

\section{Non-school-based centers}

Normally run by ministries and agencies such as Ministry of Youth and Sports, Ministry of Human Resource, Ministry of Higher Education, and State agencies, mainly for youths who have completed secondary education or a part of secondary education. The training can be variable in length, from modular courses to short courses or even lasting one to three years. At the end of the training there will be an award of certificate by the respective institutions.

\section{Enterprises or in-service training}

Courses are offered within the enterprise through on-the-job training or apprenticeship scheme. These are tailor-made courses offered by the experts within the enterprise or by people outside the enterprise. The main purpose is to equip or update knowledge or skills required of the workforce to operate new equipment or manage new projects.

\section{CONCLUSION}

It was concluded that Government should recognize the fact that technical and vocational education and training is the bedrock for any meaningful development. The problems of this form of education should be address and see how Vocational and Technical Education can be maximized 
towards productivity and sustainable development in Nigeria. It is through TVET that a nation is able to achieve a desire to become an industrialized nation. Great economies, such as China, Korea and Japan emphasized on the development of TVET in their education system. High skills acquired by students of great economies form the foundation for their continuous economic development. If Nigeria is to be like other strong economies, we need to believe that TVET can do the job. We need to put more focus on TVET. We need to change the negative perceptions by our society of TVET. We need to encourage youths to enroll in TVET programme. We need employers to recognized TVET qualification. Most importantly, we need the commitment from all parties involved in the development of country's human resource by making TVET a first choice of education rather than education for the second half of high school graduates.

\section{RECOMMENDATIONS}

The following recommendations were made to address the challenges.

1. The government, stakeholders, policy makers and TVET providers in Nigeria should focus on TVET best practices that have worked in developed countries around the world.

2. Technical educators should convince the law makers on the reasons and give priority attention to the TVET programme in resources allocation.

3. The government should adequately provide fund, plan, implement, and manage TVET programmes in technical institutions in Nigeria.

4. Provision of adequate facilities, equipment, consumable materials, and hand tools; provision of qualified TVET personnel; adequate provision of instructional materials and provision of in service training for TVET personnel are very important.

5. Provision of scholarship/grants for TVET teachers/instructors; proper supervision and monitoring of the implementation of TVET programmes.

6. The introduction of competency based TVET programmes in Nigerian technical institutions.

7. More emphasis should be stress on acquisition of technical skills for gainful employment among University graduates.

8. Also, the societal belief that TVET is education for less privileged and those that cannot do well in academics should be discourage. Access and equity of admission into technical colleges should be made available for both in rural and urban areas respectively.

9. TVET curriculum should be revised to shift from single to multiple skills, build from local market opportunities to foster local innovations and technologies than over dependence on imported ones. Its curriculum must be indigenous, through out by the people, and agreed to the people's aspirations and conditions of their natural environment, in accordance with the resources at their disposal and particular genius of their culture.

\section{REFERENCES}

[1] Afeti, G. (2006) Strategy to revitalize technical and vocational education and training (TVET) in Africa. Background document for the African Union's TVET Experts' meeting, 13-14, Addis Ababa.

[2] Alfred, S. B., \&Kayoma, F. O. (2012). Enhancing the quality of vocation agriculture in secondary schools for agricultural productivity in Nigeria (pp. 99-103). Proceedings of the 2012 Annual International Conference of the Faculty of Education,Delta State University Abraka.

[3] African Union (2007). Strategies to Revitalize Technical and Vocational Education and Training (TVET) in Africa. Final Draft of the Meeting of the Bureau of the Conference of Minister of Education of the African Union (COMEDAF II+) Addis Ababa Ethiopia.

[4] Akerele, W.O. (2007). Management of technical and vocational education in Nigeria: the challenges of the country. Journal of Research in Education and Society. 1(2\&3): 117-124.

[5] Akoojee, S. (2016). Private TVET in Africa: understanding the context and managing alternative forms creatively. Journal of Technical Education and Training, 8(2), 38 -51.

[6] Ashton, D. N.\& Sung, J. (2002). Supporting workplace learning for high performance working. Geneva: The International LabourOrganisation.

[7] Asogwa, O. \&Diogwu, G. O. (2007).Vocational and textile education in Nigeria in the 21st Century, Journal of the Nigerian Academic Forum, Volume 12(2), Awka, National Association of the Academics.

[8] Ayonmike, C.S. (2013). Status of technical and vocational education in rural institutions in Delta State Nigeria.

[9] Bakar, A. R. (2011). Preparing Malaysian youths for the world of work: Roles of technical and vocational education and training (TVET). Malaysia: Universiti Putra Malaysia Press

[10] Billet, S. (2009). The TVET profession. In R. Msclean, D. Wilson \& C. Chinien (eds) International Handbook of Education for the Changing World of Work: Bridging Academic and Vocational Learning. UNESCO-UNEVOC Handbooks and Books Series. Bonn, Springer Science and Business Media. $\mathrm{http} / /$ :www.springer.com/education+percent26+language/book/97 8-1-4020-5280-4 Accessed 12/12/2012

[11] British Council. (2017). The role of TVET governance at subnational levels. Simon Perryman and John Perryman of Perryman, Yeandle and Associates Ltd.

[12] Capelli, P. (2014). Skillgaps, skill shortages and skill mismatches: evidence for the US. NBER Working Paper 20382. Retrieved from http://www.nber.org/papers/w20382.

[13] Dee, T. S. (2007). Teachers and the gender gaps in student achievement. Journal of Human Resources, 42, 528- 554.

[14] Deloitte and Manufacturing Institute (2015). The skills gap in U.S. manufacturing: 2015 and beyond. Retrieved from http://www.themanufacturinginstitute.org/ \%/media/827DBC76533942679A15EF7067A704CD.ashx

[15] Education sector Analysis (2005). Nigeria education sector diagnosis: A framework for re-engineering the education sector (A Condensed Version). Abuja: Federal Ministry of Education

[16] Eze, C.P. (2013).Empowering the youth through technical and vocational education. A Panacea for Sustainable National Development.Unizik Orient Journal of Education. Vol. 7(1).59 64.

[17] Ezenwafor, J. (2015). Rating of strategies for transforming technical vocational education and training for the 21 st century by tertiary institutions lecturers in South-East Nigeria. International journal of education policy research and review, 2(7).

[18] Eze, T.I. \&Okorafor, A.O. (2012). New approaches to the development of technical, vocational education and training 
(TVET) curriculum for improved labour productivity. International Journal of Education Researcher 12 (1) 101-108

[19] Federal Republic of Nigeria. (2013). National policy on education. Lagos: NEDRC Press. Merriam-Webster Dictionary.

[20] Federal Ministry of Education-FME (2009). Roadmap to Nigeria education sector http://planipolis.iiep.unesco.org/upload/Nigeria/Nigeria_Roadmap. pdf Accessed 26/06/2013

[21] Federal Ministry of Education-FME (2012). 4-Year strategic plan for the development of the education sector. Abuja: Government Press

[22] Ibeneme, O.T. (2013). Roles of technical vocational education and training in transformation of developing countries: Nigerian experience. Invited Lead Paper Presented at the $1^{\text {st }}$ International Conference of the School of Technology Education Federal University of Technology, Minna; 6-10 October.

[23] Hoffman, N., \&Schwerty, B. S. (2017). Learning for careers: the pathways to prosperity network. Cambridge: Harvard Education Press.

[24] Ismail, A., Adnan, W. N., Masek, A., Hassan, R., Hashim S. \& Ismail, M. E. (2018). Effectiveness of entrepreneurship programmes in developing entrepreneurship skills towards quality TVET graduates. Journal of Technical Education and Training, 11(1), 081-086. DOI: https://doi.org/10.30880/jtet.2019.11.01.10

[25] Kayode, O.(2013). Corruption and national security in NigeriaThe role of the media http://saharareporters.com/article/corruption-and-national-securitynigeria-role-media-kayode-oladele Accessed 23/09/2013

[26] Kingombe, C. (2012). Lessons for developing countries from experience with technical and vocational education and training.International Growth Center Working Paper 11/1017. http://www.theigc.org/sites/default/files/christian_kingombe_pape r.pdf Accessed 26/06/2014

[27] May and Ajayi, I. A; Arogundadade, B.B. \&Ekundayo, H.T. (2007). Assessing realities and challenges of technical education in Imo State Secondary School Education System, in Nigeria.Journal of Educational Administration and Planning. Volume (7) March.

[28] McGowan, A. M. \& Andrews, D. (2015). Labour market mismatch and labour productivity: evidence from PIAAC data. OECD Economics Department Working Papers, No. 1209. Paris: OECD Publishing. https://doi.org/10.1787/5js1pzx1r2 kb-en

[29] Mkpa,M. A. (2014) Overview of educational development: precolonial to present day. www.onlinenigeria.comAccessed $30 / 08 / 2014$

[30] Moodie, G. (2002). Identifying vocational education and training. Journal of Vocational Education and Training, 5: 249-265.

[31] Naijapals.com, (2013).Bandits invade police station and beat police. www.gistmania.com/talk/topic,,176050.0.html Accessed 17/10/22/13 Naijapals.com (2013b). Businessman killed for refusing to settle area boys in Lagos www.gistmania.com/talk/topic,176159.0.html Accessed $18 / 10 / 2013$

[32] National Board for Technical Education - NBTE (2011). Report of the national steering committee on the development of National Vocational Qualifications Framework (NVQF) for Nigeria htt://www.nbte.gov.ng/downloads/FINAL percent2oREPORT percent 20NVQF.pdf Accessed 8/8/2014

[33] National Bureau of Statistics (2012). 2011 social statistics in Nigeria. Abuja: National press

[34] Nnajiofor, F.N. (2014). The mechanisms for social-industry linkage programme at technical colleges in Anambra and Enugu States. Ph.D. Dissertation presented to Vocational Education NnamdiAzikiwe University

[35] Nuru, A. (2007). The relevance of national Vocational education qualification (NVQS) in TVE in Nigeria Unpublished Conference Paper.

[36] Nwogu, P.O. and Nweanomo, C.C (2011). Vocational technical education and training for self-reliance: towards national development. Mediterranean Journal of Social Sciences 5(5):5559.
[37] Nworlu-Elechi, O. (2013), Technical and vocational education for national transformation" Proceeding of 1st ASUP Zone D National Conference 21-37

[38] Odu, K.O. (2011). Human capital development in science and technology education: challenges and new responsibilities for the teacher. Contemporary Educational Technology 2(3):238-249

[39] Hashim S. \& Ismail, M. E. (2018). Effectiveness of entrepreneurship programmes in developing entrepreneurship skills towards quality TVET graduates. Journal of Technical Education and Training, 11(1), 081-086. DOI: https://doi.org/10.30880/jtet.2019.11.01.10 [21]

[40] Obioma, G. (2010) Nigerian experience in technical and vocational education and training (TVET): reforms, challenges and opportunities for global Competitiveness. Keynote Address presented at the $23^{\text {rd }}$ Annual National Conference of the Nigerian Association of Teachers of Technology (NATT)

[41] OECD (2013). OECD skills outlook 2013: first results from the survey of adult skills. OECD Publishing. https://doi.org/10.1787/9789264204256-en

[42] Oganwu, P. O. (2011). Towards ensuring quality in the colleges of education: Case study of college of education Warri. Research in Education, 17(1), 166-170.

[43] Oketch, M.O. 2009. To vocatinalize or not to vocationalize? Perspectives on current trends and issues on TVET in Africa. In R. Maclean, D. Wilson and C. Chinien (eds) international Handbook of Education for the Changing World of Work: Bridging Academic and Vocational Learning. UNESCOUNEVOC Handbooks and Books series. Bonn, Springer Science and Business Media. http://www.springer.com/education+percent26+language/book/97 8-4020-5280-4 Accessed 12/12/2012

[44] Okoye, R. \&Arimonu, M. O. (2016). Technical and vocational education in Nigeria: issues, challenges and a way forward. Journal of Education and Practice, 7(3), 113 - 118. [30]

[45] Okoye, K. R. E., \&Okwelle, P. C. (2013). Technical and vocational education and training (TVET) in Nigeria and energy development, marketing and national transformation. Journal of education and practice, 4(14), 134-138.

[46] Okafoafor, C. (2010). Human capital development and vision 20:10. A perspective on tertiary education. SBMT Nekede Conference Journal. 1(2):71-73.

[47] Okorafor, A.O., Uduanochie, C.A. \&Achukwu, B.C. (2014). Sustainable mechanisms for involving industries in technology education for economic development. World Educators Forum Vol. 4 No. 1, page 87-99

[48] Omobola, J. (2013). Boosting technology education for economic development http://www.thisdaylive.com/news/ Assessed 26/06/2013

[49] Ojimba, D.P. (2012). Vocational and technical education in Nigeria: issues, problems and prospects" dimensions. Journal of Education and Social Research Vol. 2(9).

[50] Olunloyo, V.O.S. (2002), The challenges of globalization for the design of technical curriculum in developing Countries First Edition, University of Lagos Press. $217-237$.

[51] Oranu, R. N. (2004). Vocational and technical education in Nigeria Retrieved June, 5, 2015

[52] Oviawe, J. I. (2018). Revamping technical, vocational education and training through public-private partnerships for skill development. Journal of Higher Education, 10(1), 73-91.

[53] Owolabi H.O. (2003). Technical and vocational education in Nigeria. In J.O.O. Abiri (ed) perspective on education in Nigeria https://www.unilorin.edu.ng/publications/owolabiho/4percent20V ocational percent20Education.pdfAccessed 31 August, 2014

[54] Onyesom, M., \&Ashibogwu, N. K. (2013). Towards quality assurance in business education in Nigeria: Constraints and control. Asian Journal of Business Management, 5(3), 306-312.

[55] Park, M. G. (2005, September). Vocational content in mass higher education? In responses to the challenges of the labour market and the work-place, Bonn, $8-10$ 
[56] Remington, T. F. (2017). Public-private partnerships in VET: translating the German model of dual education. Moscow: HSE Publishing House.

[57] Remington, T. F. (2018). Public-private partnerships in TVET: Adapting the dual system in the United States. Journal of Vocational Education and Training, 70(4), 497-523.

[58] The Nation (2013) How Nigeria came into being in 1914 http://thenationonlineng.net/new/how-nigeria-came-into-beng-in1914/ Accessed 31 August, 2014

[59] UNDP (2013) Human development report 2012 - The rise of the south: Human progress in a diverse World. Canada: Gilmore Printing Services

Inc. http://www.undp.org/content/dam/undp/library/corporate/HDR/20 13GlobalHDR/English/HDR2013 percent20Report percent20English.pdf Accessed 14/07/2013

[60] UNESCO (2009). Regional overview: Sub-saharan Africa; overcoming inequality. UNESCO EFA Global Monitoring Report. Paris: UNESCO.

[61] UNESCO (2009). Education for all-global monitoring report: reaching the marginalized. http://unedoc.unesco.org/images/0018001865/186525e.pdf Accessed 30/08/3014

[62] UNESCO Institute for Statistice- UIS (2009). Participation in fromal and vocational education and training programmes, worldwide-an Initial Study. Bonn.UNESCO.

[63] UNESCO, ILO (2002) Revised Recommendation concerning Technical and Vocational Education (2001). Paris: UNESCO; Geneva, Switzerland: ILO. http//unesdoc.unesco.org

[64] Umunadi, E. K. \&Uwameiye, R. (2015). Technical education graduate skill development as perceived by employers in institution and industries in Delta State. Studies in Education, 15(1) 90-97. www.dailypost.ng. (2018). Retrieved on 22nd June, 2018.

[65] Uwaifo, V. O., \&Uwaifo, I. U. (2009). Training technology and vocational education teachers for the new 9-3-4 education system in Nigeria: Its problems and prospects. International NGO Journal, 4(4), 146-159

[66] Valmonte, L.D. (2009). Achieving sustainable development through TVET - experiences of international organizations working with member States in Asian and the Pacific. www.googlesearch.comAccessed 11/04/2010.

[67] The White House (2018). How China's economic aggression threatens the technologies and intellectual property of the United States and the world. White House Office of Trade and Manufacturing Policy. https://www.whitehouse.gov/wpcontent/uploads/2018/06/FINAL-China-Technology-Report6.18.18-PDF.pdf

[68] Wikipedia, (2014). History of Nigeria. http://en.wikipedia.org/wiki/Historyof Nigeria.Accessed 31 August, 2014.

[69] Wikipedia, (2013).Women in education in Nigeria http://en.wikipedia.org Accessed 08/04/2013

[70] Wilson, D. N. (2005). The education and training of knowledge workers. In J. Zajda (ed.), International Handbook on Globalization, Education and Policy Research, 49-64

[71] World Bank, (2000) African development indicators 2000. Washington DC: World Bank

[72] World Bank, (2013). Gini index. www.worldbank.org Accessed 08/07/2013

[73] Wright, J. (2013). America's skilled trades' dilemma: shortages loom as most-in-demand group of workers ages. Forbes. https://www.forbes.com/sites/emsi/2013/03/07/americas-skilledtrades-dilemmashortages-loom-as-most-in-demand-group-ofworkersages/\#28d515186397.

[74] Xinyu, T. (2019). Employment rate remains steady in China. https://chinadaily.com.cn/a/201902/25/WS5c738815a3106c65c34 eb420.html

[75] Yang, J. (2008), General or vocational? The Tough choice in the Chinese education policy, International Journal of Educational Development 18(4), 289-304। 